\title{
Synthesis, Electrochemical Characterization and Photocatalytic Application of Ceion Doped ZnO nanoparticles using Leaf Extract of SesbaniaGrandiflora by Green Method
}

\author{
Muthu Chudarkodi R R. ${ }^{1}$, Rajalaxshmi A. ${ }^{2}$ \\ ${ }^{1}$ Department of Chemistry, V.O.Chidambaram College, Tuticorin-628 008, TamilNadu, India \\ ${ }^{2}$ Department of Chemistry, A.P.C Mahalaxmi College for Women, Tuticorin-628 002, TamilNadu, India
}

\begin{abstract}
Nanosized ZnO particles of specific morphology were synthesized using the plant leaf extracts of Sesbaniagrandiflora (Agathikeerai). The structures and morphology of these fabricated $\mathrm{ZnO}$ naoparticles and Ce ion doped ZnO nanoparticles were characterized by FTIR, SEM-EDAX, AFM and PL. Photodegradation and electrochemical behavior of the nanoparticles were studied. The aqueous SesbaniaGrandiflora leaf extract acts as a solvent with multiple roles as promoter and capping agent for the synthesis of $\mathrm{ZnO}$ and $\mathrm{Ce}$ ion doped $\mathrm{ZnO}$ nanoparticles. Photocatalytic degradation was also investigated with Bismarck brown dye under UVirradiation source. The $\mathrm{ZnO}$ and $\mathrm{Ce}$ ion doped $\mathrm{ZnO}$ nanoparticles exhibited potential photocatalytic activity towards the degradation of Bismarck brown dye. Green synthesis using SesbaniaGrandiflora is found to be the best capping agent for synthesizing nanoparticles.
\end{abstract}

Keywords: Zinc oxide nanoparticles, Green synthesis, SesbaniaGrandiflora, FT-IR, SEM-EDAX, AFM, PL, Photodegradation, Electrochemical studies

\section{Introduction}

Green synthesis techniques make use of moderately pollutant free chemicals to synthesis nanomaterials and embrace the use of benign solvents such as water, natural extracts. Green chemistry seeks to reduce pollution at source [1,2].The advantage of using plants for the synthesis of nanoparticles is that they are easily available, safe to handle and possess a broad variability of metabolites that may aid in reduction. A number of plants are being currently investigated for their role in the synthesis of nanoparticles. $\mathrm{ZnO}$ belongs to the class of metal oxides, which is characterized by photo catalytic and photo-oxidising capacity against chemical and biological species [3].Green synthesis of zinc oxide nanoparticles using Aloe vera [4], gold nanoparticles by alfalfa [5], Cinnamomumcamphora [6], neem [7], Emblicaofficianalis [8], lemongrass [9] and tamarind [10] has been reported. Therefore the present investigation has been made to synthesize $\mathrm{ZnO}$ nanoparticles by SesbaniaGrandiflora.

\section{Sesbaniagrandiflora}

SesbaniagrandifloraL. is a plant from family fabaceae cultivated in all over India for its edible flowers. It has synonym Agatigrandiflora (Fig.1)and commonly known as Hummingbird Tree, Butterfly Tree. It's one of the wellknown medicinal plants of India. Sesbaniagrandiflora has been known to have antimicrobial activities [11, 12].

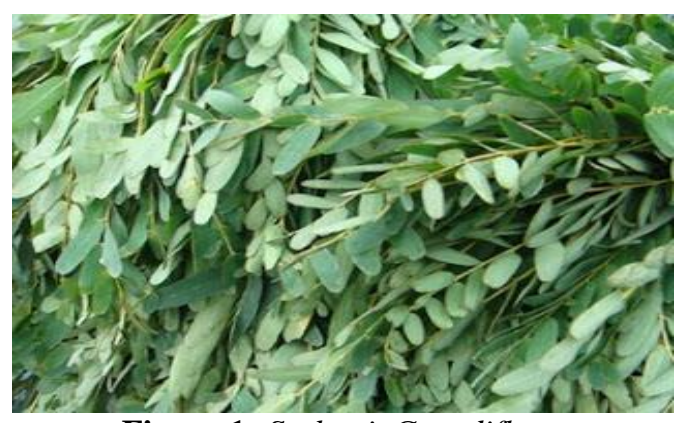

Figure 1: SesbaniaGrandiflora

It is a 3-8 $\mathrm{m}$ long and the colour of the flowers is red and white in colour. It containsalkaloids, phenols, flavonoids, carbohydrates, saponins, phytosterols, Triterpenes [13], amino acids and alcohol [14].Leaves are used to disinfect throat and cure kidney diseases. Saponins have been extensively used as detergents, pesticides and molluscicides and also have beneficial health effects.

\section{Experimental Methods}

\subsection{Collection of Plant}

The plant Sesbaniagrandiflora was collected in the surroundings of Tirunelveli district, Tamilnadu.

\subsection{Preparation of theleaf extract}

The collected SesbaniaGrandiflora leaves were washed several times with water to remove the impurities. Leaves had been dried in the sun shade for 7 days. After the leaves were dried, it is powdered using mortar. The SesbaniaGrandiflora leaf powder of $10 \mathrm{~g}$ was used for 


\section{International Journal of Science and Research (IJSR) \\ ISSN (Online): 2319-7064 \\ Index Copernicus Value (2013): 6.14 | Impact Factor (2014): 5.611}

synthesis purpose. The weighed $10 \mathrm{~g}$ leaf powder was mixed gently with $100 \mathrm{ml}$ of distilled water, boiled in $80^{\circ} \mathrm{C}$ for $60 \mathrm{~min}$; until the colour of the solution changes from watery to yellow. Then the extract was filtered through Whatman No.1 filter paper, stored at room temperature in order to use for further studies.

\subsection{Synthesis of $\mathrm{ZnO}$ nanoparticles and $\mathrm{Ce}$ ion doped ZnO nanoparticlesusing Sesbaniagrandiflora leaf extract:}

$5 g$ Zinc Nitrate was added to the leaf extract under vigorous stirring. After $15 \mathrm{~min}$ stirring the solution was heated at a temperature of about $60^{\circ} \mathrm{C}$. The yellow coloured paste was finally calcined at $400^{\circ} \mathrm{C}$ for $2 \mathrm{~h}$. TheZnO nanoparticles so obtained were preserved in the air-tight vials for further studies [15]. Similar procedure was adopted for the synthesis of Ce ion doped $\mathrm{ZnO}$ nanoparticles using 1\% cerium nitrate as the precursor material.

\subsection{Photocatalytic Measurement:}

NanosizedZnO particle is a good photocatalyst to degrade organic contaminants, such as Bismarck brown dye. The dye solution was prepared by dissolving $10 \mathrm{mg}$ powder of Bismarck brown dye in $100 \mathrm{ml}$ distilled water.0.1g nanoparticles was added to $100 \mathrm{ml}$ of prepared Bismarck browndye solution and the mixer was stirred magnetically for 60min in shadow before exposing to sunlight. Then the colloidal suspension was placed in a closed chamber and irradiated with sunlight. The reactions were observed one by one in every time interval of $10 \mathrm{~min}$ for $1 \mathrm{hr}$. Finally, the rate of dye decomposition was monitored by taking $4 \mathrm{ml}$ samples from each set and recording the UV-Vis spectra in the wavelength after centrifugation and filtration [16].

\subsection{Instrumentation}

Nicolet iS5 instrument was used to identify the functional groups of the synthesized zinc oxide nanoparticles. The surface morphology of the nanoparticles was done using Carl Zeiss EVO 18 SEM operating at $15 \mathrm{KV}$ using normal incidence. EDAX measurements were carried out by Quantax 200 with X-Flash-Bruker. The electrochemical analyzer, $\mathrm{CH}$ Instruments Electrochemical Workstation model 650C was employed for various electrochemical studies performed in this study.

\section{Results and Discussion}

\subsection{FT-IR Studies:}

The FTIR spectrum of $\mathrm{ZnO}$ nanoparticles synthesized using aqueous leaf extract of SesbaniaGrandiflora was shown in the Fig.2. The broad peak located at $3444.88 \mathrm{~cm}^{-1}$ can be assigned to the $\mathrm{O}-\mathrm{H}$ stretching vibrations, indicating the presence of hydroxyl groups [17]. Few less intense peaks centered at2923.69 $\mathrm{cm}^{-1}, 2853.34 \mathrm{~cm}^{-1}$ and $2426.27 \mathrm{~cm}^{-1}$ are probably due to presence of aliphatic asymmetric C-H stretching vibration, $\mathrm{C}-\mathrm{H}$ stretching and $\mathrm{O}-\mathrm{H}$ stretching in carboxylic acid respectively [18].The peak at $1795.46 \mathrm{~cm}^{-1}$ can be assigned to the $-\mathrm{C}=\mathrm{O}$ - group and the peak at 1763.17 $\mathrm{cm}^{-1}$ can be assigned to the C-O-C stretching of polysaccharides present in the SesbaniaGrandiflora leaf extract [19].Moreover, the peaks at $1384.24 \mathrm{~cm}^{-1}$ and $1627.76 \mathrm{~cm}^{-1}$ were mainly attributed to the $-\mathrm{C}=\mathrm{N}$ - stretching vibrations as well as amide bands of proteins [20]. In addition, there is a peak at $1421.91 \mathrm{~cm}^{-1}$ corresponds to $\mathrm{O}-\mathrm{H}$ bending of the hydroxyl group present. The bands at 1162.65 and $1121.27 \mathrm{~cm}^{-1}$ can be attributed to the -C-Ostretching and $\mathrm{O}-\mathrm{H}$ deformation assigned to the water molecule respectively.

The frequency observed at $917.52 \mathrm{~cm}^{-1}$ corresponds to $\mathrm{O}-\mathrm{H}$ bending of carboxylic acid present. The peak at $875.25 \mathrm{~cm}^{-1}$ was due to the formation of tetrahedral coordination of $\mathrm{Zn}$ ion [21]. The peaks observed at $825.62 \mathrm{~cm}^{-1}$ and $839.32 \mathrm{~cm}^{-1}$ are due to the weak band (result of $\mathrm{C}-\mathrm{H}$ out of plane bending) and aromatic -C-H- out of plane bending respectively. The peak at $712.87 \mathrm{~cm}^{-1}$ is due to the presence of $\mathrm{R}-\mathrm{CH}$ group. The peak at $679.40 \mathrm{~cm}^{-1}$ indicates the stretching vibrations of $\mathrm{ZnO}$ nanoparticles which is consistent with the reported data [22]. The characteristic peak appeared at $439.38 \mathrm{~cm}^{-1}$ could be attributed to the metal oxygen ( $\mathrm{Zn}-\mathrm{O})$ bond.

Fig.3. shows the FTIR spectrum of $\mathrm{Ce}$ ion doped $\mathrm{ZnO}$ nanoparticles synthesized using aqueous leaf extract of SesbaniaGrandiflora. The broad peak located at $3444.51 \mathrm{~cm}^{-}$ 1 can be assigned to the $\mathrm{O}-\mathrm{H}$ stretching vibrations, indicating the presence of hydroxyl groups. The peak centered at $2925.62 \mathrm{~cm}^{-1}$ corresponds to aliphatic asymmetric -C-H- stretching vibration. The peaks at 1500.26 $\mathrm{cm}^{-1}$ and $1629.41 \mathrm{~cm}^{-1}$ are due to $-\mathrm{C}-\mathrm{H}$ - stretching and $\mathrm{C}=\mathrm{O}$ - stretch in polyphenols respectively. The bands at $1384.20 \mathrm{~cm}^{-1}$ and $1141.35 \mathrm{~cm}^{-1}$ can be attributed to the aromatic $-\mathrm{C}=\mathrm{C}$ - bond, $-\mathrm{O}-\mathrm{C}-$ stretching respectively. The peak located at around $1063.58 \mathrm{~cm}^{-1}$ can be assigned as the absorption peak of $-\mathrm{C}-\mathrm{O}-\mathrm{C}-$ or $-\mathrm{C}-\mathrm{O}-$ stretching. The peak around at $596.39 \mathrm{~cm}^{-1}$ indicating the formation of stretching mode of Ce ion doped $\mathrm{ZnO}$ [23]. The peaks corresponding to $\mathrm{Zn}-\mathrm{O}$ bonds are shifted towards lower wavenumber for $\mathrm{Ce}$ doped $\mathrm{ZnO}$ nanoparticles, indicating the incorporation of $\mathrm{Ce}$ ions in the $\mathrm{ZnO}$ lattice [24]. The bands obtained at 659.53, $612.25,496.91$ and $443.59 \mathrm{~cm}^{-1}$ are due to the characteristic stretching vibrations of $\mathrm{ZnO}$ nanoparticles [25].

\subsection{FT-IR Spectrum}




\section{International Journal of Science and Research (IJSR) \\ ISSN (Online): 2319-7064}

Index Copernicus Value (2013): 6.14 | Impact Factor (2014): 5.611

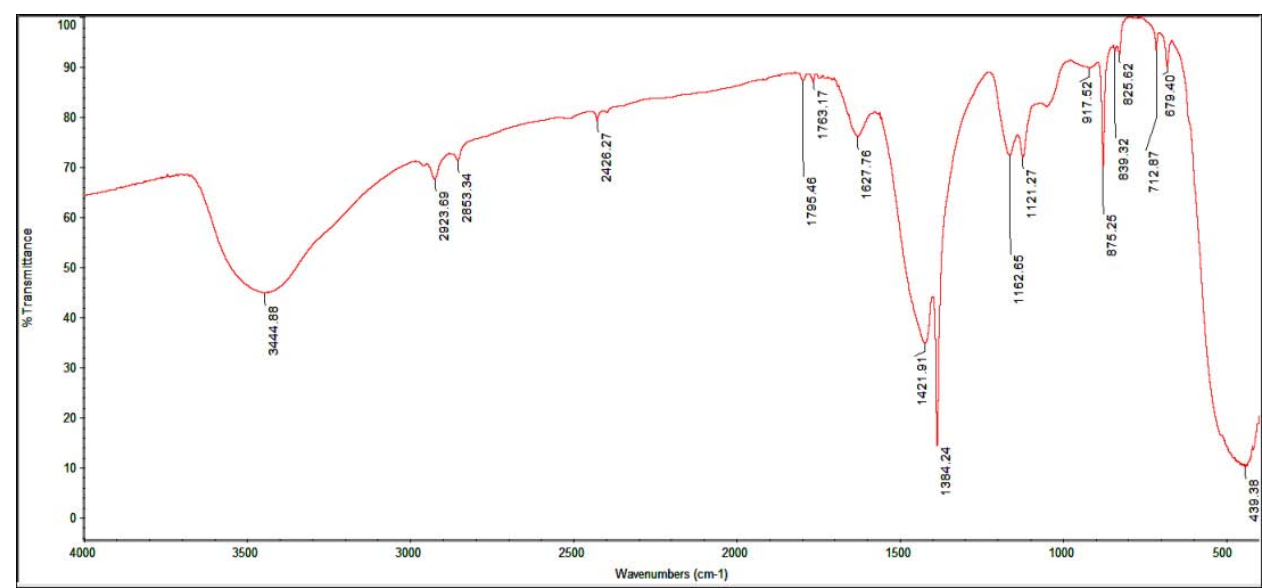

Figure 2: FTIR spectrum of $\mathrm{ZnO}$ nanoparticles synthesized using SesbaniaGrandiflora leaf extract

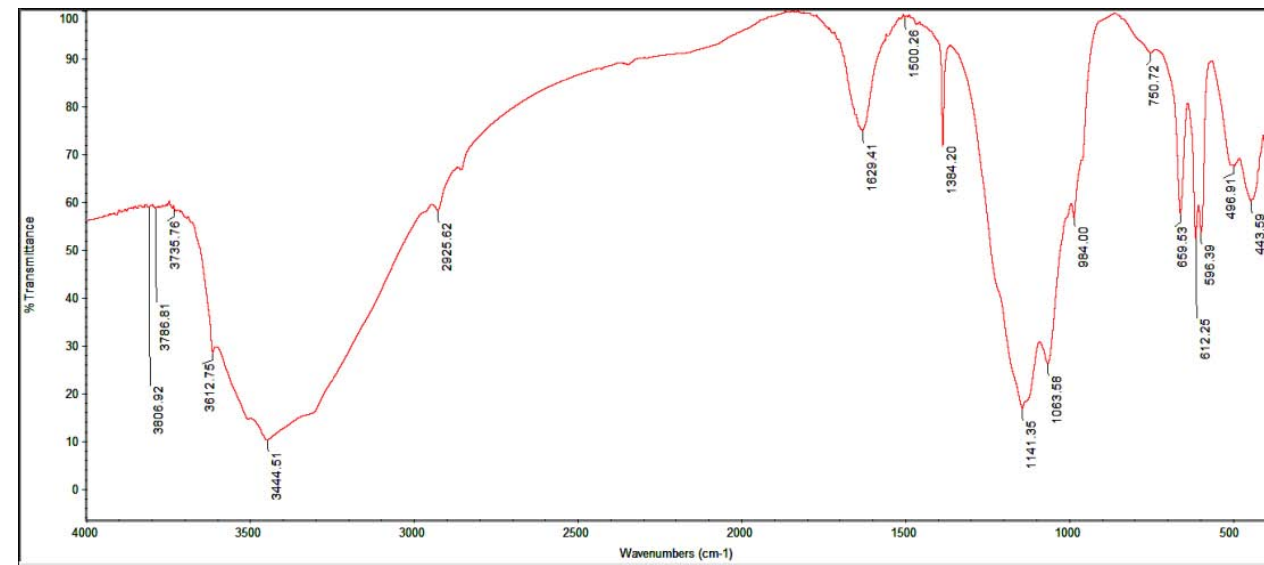

Figure 3: FTIR spectrum of Ce ion doped ZnO nanoparticles synthesized using SesbaniaGrandiflora leaf extract

\subsection{SEM Analysis}

Fig.4 represents the SEM image of $\mathrm{ZnO}$ nanoparticles synthesized using SesbaniaGrandiflora leaf extract. This picture substantiates the approximate spherical shape to the $\mathrm{ZnO}$ nanoparticles with a granular nature, and most of the particles exhibit some agglomeration [26]. The aggregation of particles should have been originated from the large specific surface area and high surface energy of $\mathrm{ZnO}$ nanoparticles [27]. The aggregation occurred may be probably due to the drying process [28, 29]. Fig.5 shows the SEM image of Ce ion doped zinc oxidenanoparticles synthesized using SesbaniaGrandiflora leaf extract and it exhibited distinct spherically balllike structure.

\subsection{SEM Image}

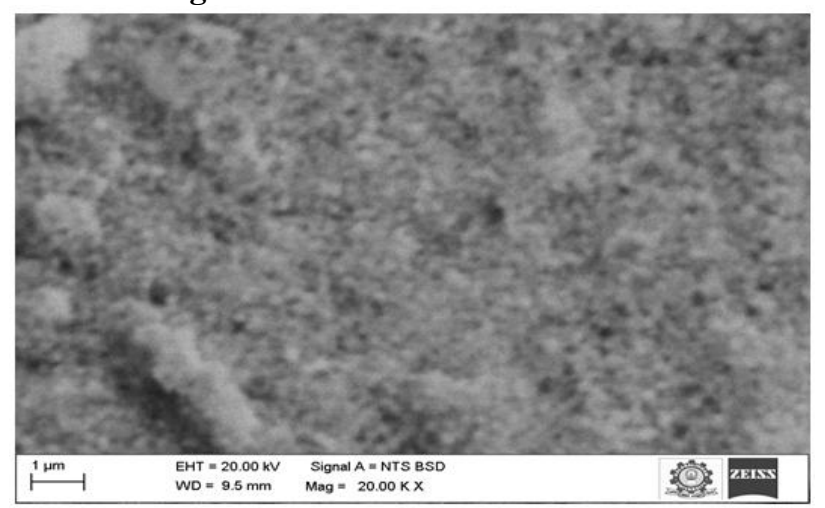

Figure 4: SEM image of ZnO nanoparticles synthesized using Sesbania Grandiflora leaf extract

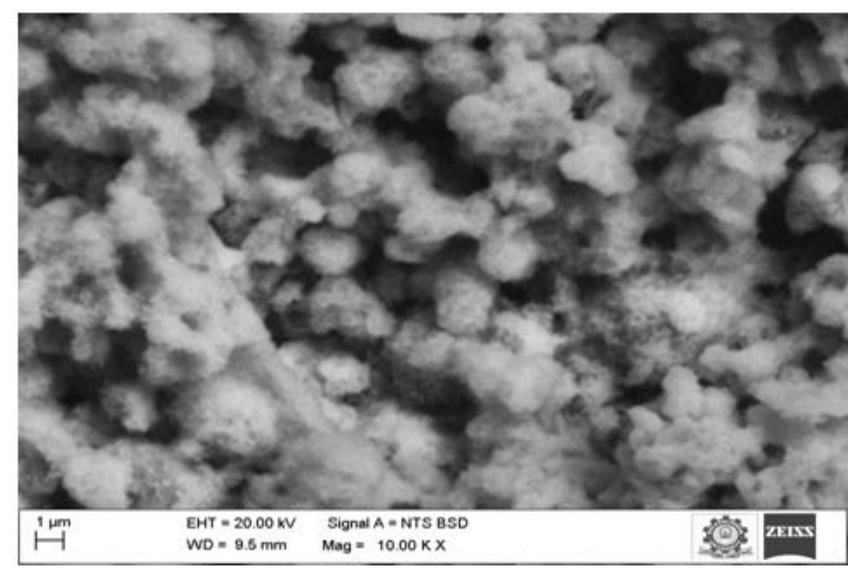

Figure 5: SEM image of Ce ion doped $\mathrm{ZnO}$ nanoparticles synthesized using Sesbania Grandiflora leaf extract

\subsection{Energy Dispersive X-Ray Analysis}

In order to confirm the presence of $\mathrm{Ce}$ ion doped $\mathrm{ZnO}$ nanoparticles synthesized using Sesbaniagrandiflora we perform the EDAX spectroscopy. Fig.6. shows the EDAX spectrum of $\mathrm{Ce}$ ion doped zinc oxide nanoparticles synthesized using Sesbaniagrandiflora leaf extract. Ce ion doped zinc oxide nanoparticles were found to have atomic percentage 37.61 of Zn, 19.86 of $\mathbf{O}, 6.31$ of Ceas shown in Table 1.This confirmed the doping of $\mathrm{Ce}$ ion in $\mathrm{ZnO}$ lattice. 


\section{International Journal of Science and Research (IJSR) \\ ISSN (Online): 2319-7064}

Index Copernicus Value (2013): 6.14 | Impact Factor (2014): 5.611

\subsection{EDAX Image}

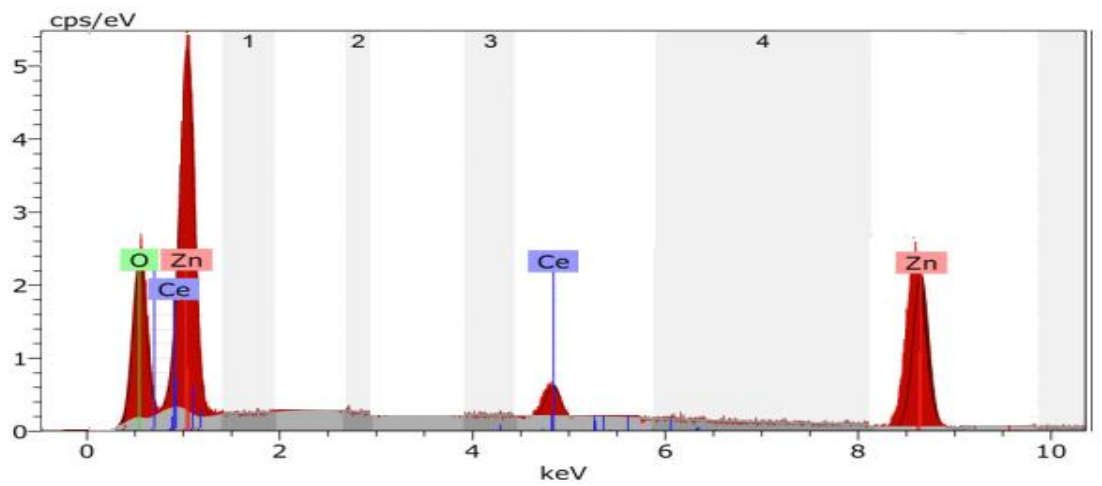

Figure 6: EDAX spectrum of Ce ion doped ZnO nanoparticles synthesized using Sesbaniagrandiflora leaf extract

Table 1: Atomic composition of Ce ion doped $\mathrm{ZnO}$ nanoparticles synthesized using Sesbaniagrandiflora leaf extract

\begin{tabular}{|c|c|c|c|c|c|}
\hline Element & Series & $\begin{array}{c}\text { Unn.C } \\
\text { [wt.\%] }\end{array}$ & $\begin{array}{c}\text { Norm.C } \\
\text { [wt.\%] }\end{array}$ & $\begin{array}{c}\text { Atom.C } \\
\text { [at.\%] }\end{array}$ & $\begin{array}{c}\text { Error (3 sigma) } \\
\text { [wt.\%] }\end{array}$ \\
\hline Zinc & K-series & 37.61 & 58.97 & 30.90 & 3.22 \\
Oxygen & K-series & 19.86 & 31.13 & 66.68 & 7.68 \\
Cerium & L-series & 6.31 & 9.90 & 2.42 & 0.64 \\
\hline \multicolumn{2}{|r|}{ Total } & 63.78 & 100.00 & 100.00 & \\
\hline
\end{tabular}

\subsection{AFM Spectral Studies}

AFM spectra were recorded for the $\mathrm{ZnO}$ and Ce ion doped $\mathrm{ZnO}$ nanoparticles deposited on the glass plate. Fig.7. shows the AFM spectral image of $\mathrm{ZnO}$ nanoparticles synthesized using Sesbaniagrandiflora leaf extract with a scanning area to $0 \mathrm{~m} \mathrm{X} 3.13 \mu \mathrm{m}$, we found spongy shape distributed over the surface [30]. These particles are between $0 \mathrm{~m} \mathrm{Y} 3.13 \mu \mathrm{m}$ in length and the size is in the range of $20-50 \mathrm{~nm}$. Fig.8.shows the AFM spectral image of Ce ion doped $\mathrm{ZnO}$ nanoparticles synthesized using Sesbaniagrandiflora leaf

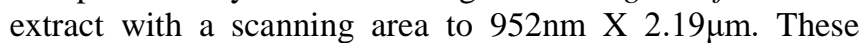
particles are between $1.89 \mu \mathrm{m}$ Y $3.13 \mu \mathrm{m}$ in length. The shape of Ce ion doped $\mathrm{ZnO}$ nanoparticles is spongy layered form and the size is in the range of $30-50 \mathrm{~nm}$.

\subsection{AFM Image}

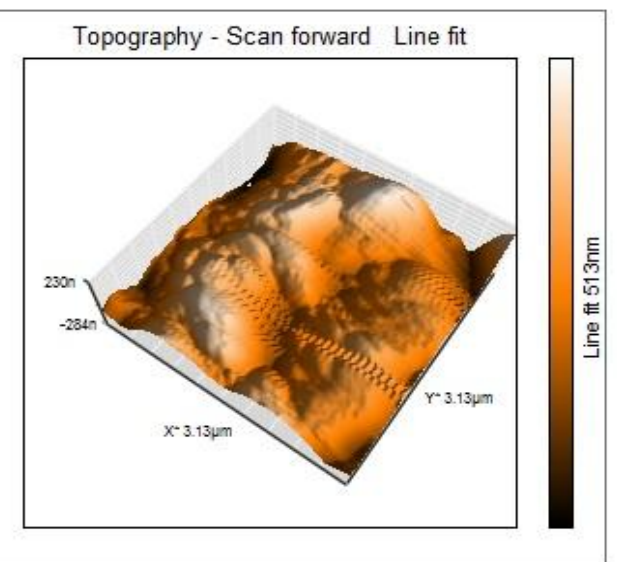

Figure 7: AFM image of ZnO Nanoparticles synthesized using SesbaniaGrandiflora leaf extract
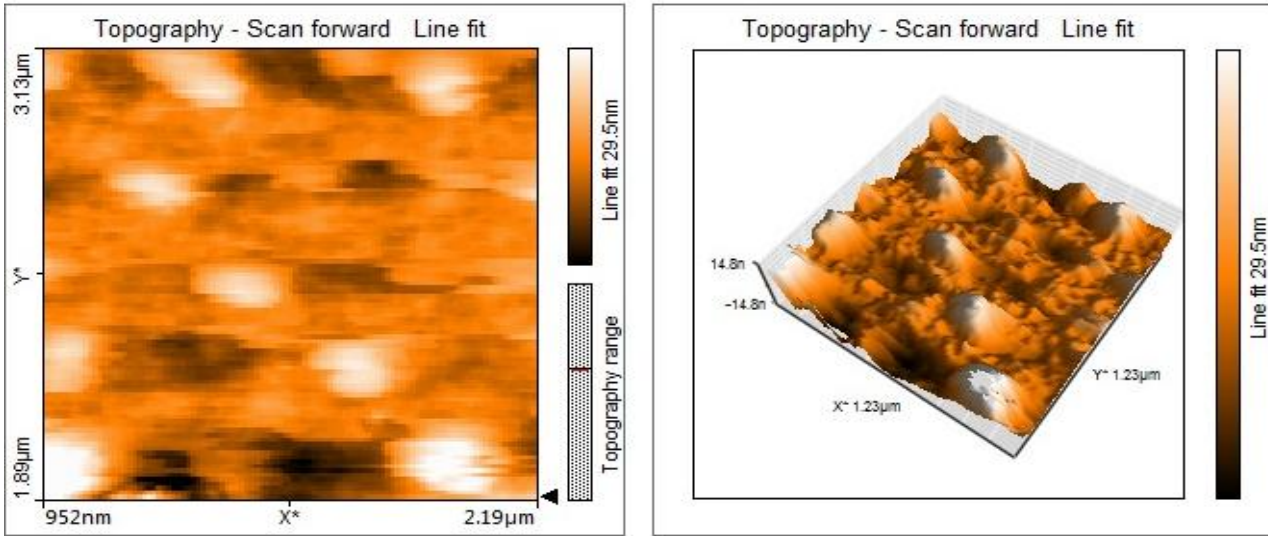

Figure 8: AFM image of Ce ion doped ZnO Nanoparticles synthesized using SesbaniaGrandiflora leaf extract 


\section{International Journal of Science and Research (IJSR) \\ ISSN (Online): 2319-7064 \\ Index Copernicus Value (2013): 6.14 | Impact Factor (2014): 5.611}

\subsection{Photoluminescence}

PL spectra were measured for the $\mathrm{ZnO}$ and Ce ion doped $\mathrm{ZnO}$ nanoparticles synthesized using aqueous leaf extract of Sesbaniagrandiflora in the range of $200-700 \mathrm{~nm}$ are shown in Fig.9 and Fig.10. The wavelength of excitation chosen for the samples is $350 \mathrm{~nm}$. It is interesting to note from that although the excitation spectra of $\mathrm{ZnO}$ and $\mathrm{Ce}$ ion doped $\mathrm{ZnO}$ nanoparticles appear similar, an appreciable change in luminescence intensity is observed in the doped samples compared to the undoped samples. For doped samples there is increase in excitation intensity. This might be due to the interaction between $\mathrm{Ce}$ ion and $\mathrm{ZnO}$ lattice. This provides an obvious evidence for the entry of Ce ion in the $\mathrm{ZnO}$ lattice. Photoluminescence investigation evidenced the high crystalline nature of the undoped and doped $\mathrm{ZnO}$ nanoparticles.

\subsection{PL Spectrum}

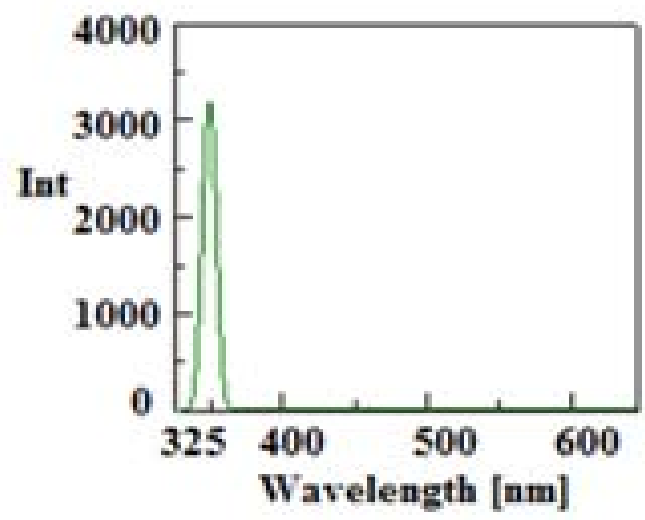

Figure 9: PL spectra of $\mathrm{ZnO}$ nanoparticlesion

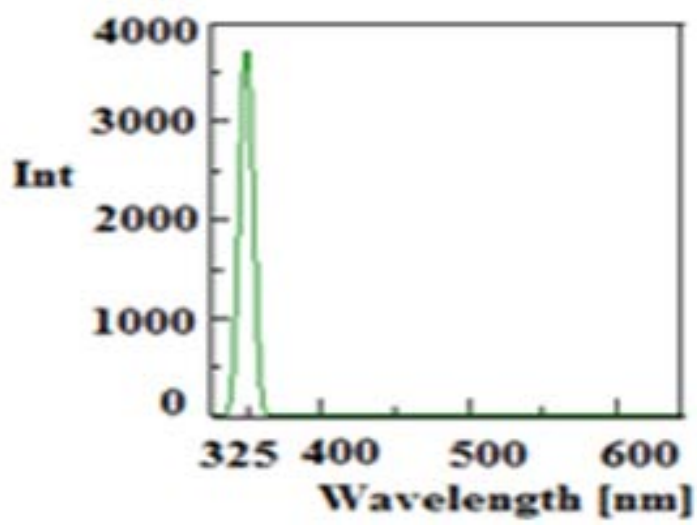

Figure 10: PL spectra of Ce doped $\mathrm{ZnO}$ nanoparticles

\subsection{Electrochemical Analysis}

\subsubsection{Electrochemical Impedance Measurements}

EIS measurements were obtained in the frequency range from $100000 \mathrm{~Hz}$ to $0.01 \mathrm{~Hz}$ by using amplitude of $0.5 \mathrm{~V}$. EIS was applied to study the resistance ability of the $\mathrm{ZnO}$ and Ce ion doped $\mathrm{ZnO}$ nanoparticles. The Nyquist plot representation of impedance spectra of green synthesized $\mathrm{ZnO}$ and $\mathrm{Ce}$ ion doped $\mathrm{ZnO}$ nanoparticles in $\mathrm{pH}=1$ medium were shown in Fig.11and Fig.12. The different parameters were tabulated (Table.2). The values of charge transfer resistance increases for $\mathrm{ZnO}$ and $\mathrm{Ce}$ ion doped $\mathrm{ZnO}$ nanoparticles when compared to the bare. The values of conductance are high for $\mathrm{ZnOand} \mathrm{Ce}$ ion doped $\mathrm{ZnO}$ nanoparticles when compared to the bare. These facts reveal that both the $\mathrm{ZnO}$ and $\mathrm{Ce}$ ion doped $\mathrm{ZnO}$ nanoparticles have high conductivity.

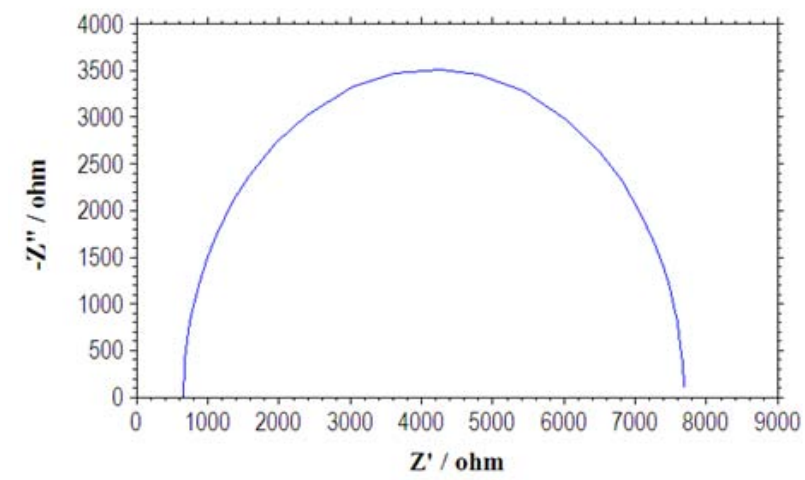

Figure 11: EIS of undoped $\mathrm{ZnO}$ nanoparticles synthesized using SesbaniaGrandiflora Leaf extract

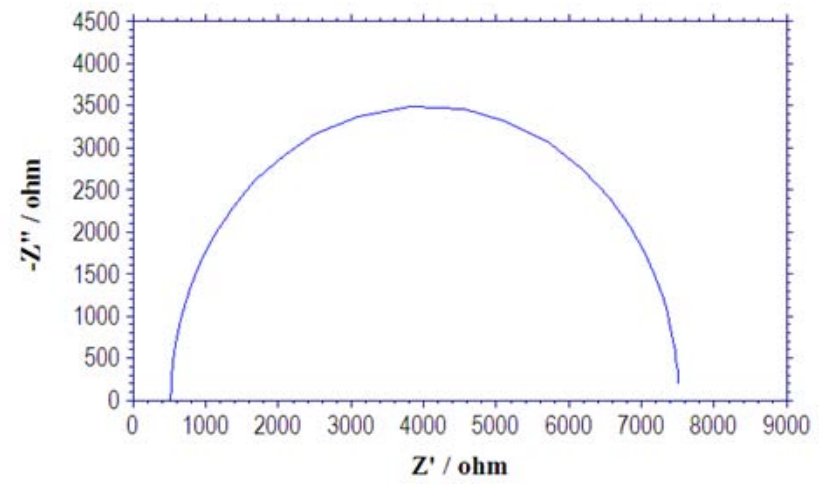

Figure 12: EIS of Ce ion doped $\mathrm{ZnO}$ nanoparticles synthesized using SesbaniaGrandiflora Leaf extract

Table 2

\begin{tabular}{|l|c|c|c|c|}
\hline Name of Plant material & Nanoparticles & $f_{\max }$ & $\begin{array}{c}R_{c t} \\
\left(\Omega \mathrm{cm}^{-2}\right)\end{array}$ & $\begin{array}{c}C_{\mathrm{dl}} \\
\left(\mu \mathrm{Fcm}^{-2}\right)\end{array}$ \\
\hline \multirow{2}{*}{ SesbaniaGrandiflora } & Bare & 2165 & 4314 & 1.704 \\
\cline { 2 - 5 } & $\mathrm{ZnO}$ & 3559 & 6922 & 6.46 \\
\hline & $\mathrm{Ce} \mathrm{ZnO}$ & 3546 & 6976 & 6.43 \\
\hline
\end{tabular}

\subsubsection{Cyclic Voltammetry}

Cyclic voltammograms were recorded in the $\mathrm{pH} 1.0$ for 1.0 $\mathrm{ml}$ of $\mathrm{ZnO}$ and Ce ion doped $\mathrm{ZnO}$ nanoparticles synthesized using aqueous leaf extract of SesbaniaGrandiflora. The Glassy Carbon Electrode was (GCE) as working electrode Vs Ag/AgCl. ZnOnanoparticles and Ce ion doped $\mathrm{ZnO}$ nanoparticles showed one oxidation peak and one reduction peak in $\mathrm{pH} 1$ conditions. The background current was recorded for all sweep rates studied in the potential range from -1.0 to $1.0 \mathrm{~V}$ and subtracted properly in calculating the peak currents.

The cyclic voltammetricbehaviour of $1.0 \mathrm{ml}$ of ZnOnanoparticlesin $0.1 \mathrm{M} \mathrm{H}_{2} \mathrm{SO}_{4}(\mathrm{pH} 1.0)$ was studied at GCE as shown in Fig.13. In this cyclic voltammogram, one sharp anodic peak and one cathodic peak were observed in the potential range from $-1.0 \mathrm{~V}$ to1.0V. The cathodicand anodic peaks were seen around the potential at $-0.7123 \mathrm{~V}$ and $0.3256 \mathrm{~V}$ respectively. The values of peak current and peak potential are presented in Table 3. 


\section{International Journal of Science and Research (IJSR) \\ ISSN (Online): 2319-7064 \\ Index Copernicus Value (2013): 6.14 | Impact Factor (2014): 5.611}

The cyclic voltammetricbehaviour of $1.0 \mathrm{ml}$ of $\mathrm{Ce}$ ion dopedZnOnanoparticlesin $0.1 \mathrm{M} \mathrm{H}_{2} \mathrm{SO}_{4}(\mathrm{pH} 1.0)$ was studied at GCE as shown in Fig.14. In this cyclic voltammogram, one sharp anodic peak and one small cathodic peak were observed in the potential range from $-1.0 \mathrm{~V}$ to1.0V. The cathodic and anodic peaks were seen around the potential at $-0.6789 \mathrm{~V}$ and $0.4291 \mathrm{~V}$ respectively. The values of peak current and peak potential are presented in Table 3.The peak potentials obtained for doped samples were entirely different from the behaviour obtained for undoped samples confirming the formation of doped samples.

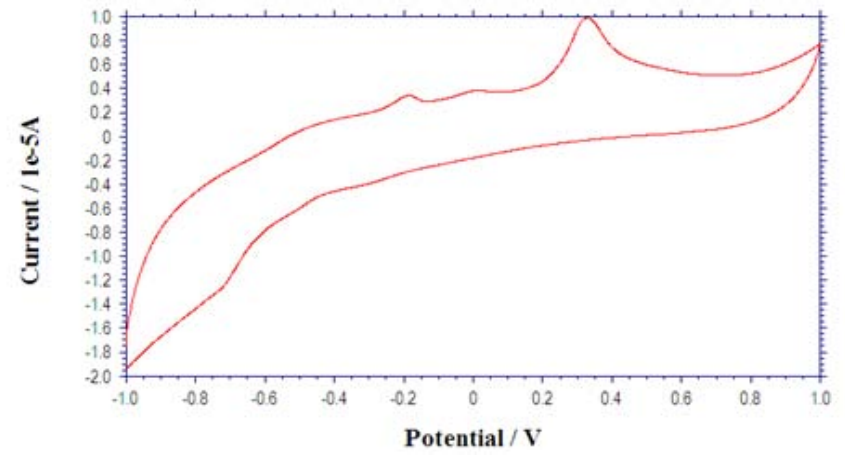

Figure 13: Cyclic Voltammogram of $\mathrm{ZnO}$ nanoparticles synthesized Using SesbaniaGrandiflora leaf extract

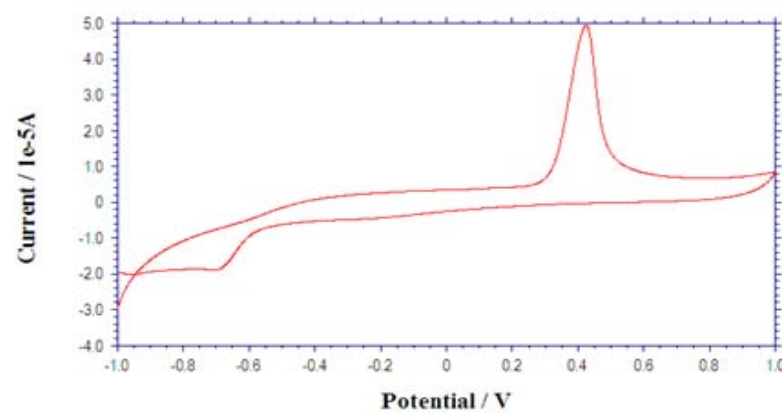

Figure 14: Cyclic Voltammogram of Ce ion doped $\mathrm{ZnO}$ nanoparticles synthesized using SesbaniaGrandiflora leaf extract

Table 3: Cyclic voltammetricbehaviour data of $\mathrm{ZnO}$ and $\mathrm{Ce}$ ion doped $\mathrm{ZnO}$ nanoparticles in $\mathrm{pH} 1.0$

\begin{tabular}{|c|c|c|c|c|c|}
\hline Name of Plant material & Nanoparticles & \multicolumn{2}{|c|}{ Oxidation } & \multicolumn{2}{c|}{ Reduction } \\
\hline & & $\mathrm{E}(\mathrm{V})$ & $\mathrm{I}(\mathrm{A})$ & $\mathrm{E}(\mathrm{V})$ & $\mathrm{I}(\mathrm{A})$ \\
\hline \multirow{2}{*}{ SesbaniaGrandiflora } & $\mathrm{ZnO}$ & 0.3256 & $9.664 \times 10^{-6}$ & -0.7123 & $-1.247 \times 10^{-5}$ \\
\cline { 2 - 6 } & $\mathrm{Ce}: \mathrm{ZnO}$ & 0.4291 & $4.899 \times 10^{-5}$ & -0.6789 & $-1.839 \times 10^{-5}$ \\
\hline
\end{tabular}

\subsection{Photocatalytic Activity}

The UV visible absorbance values of pure Bismarck brown dye solution shows absorption wavelength at $460 \mathrm{~nm}$. The characteristic absorbance value at $460 \mathrm{~nm}$ was used to track the photocatalytic degradation process. Fig.15can be clearly noticed from the recorded values that no significant changes of the concentration of Bismarck brown dye after 3 hrs irradiation, which indicated that pure Bismarck brown dye solution,cannot be easily degraded by UV light. The degradation efficiency of pure Bismarck brown dye within 3 hrs irradiation time was about $28 \%$. The result showed that the photocatalytic activity of pure Bismarck brown dye was very less when compared with the $\mathrm{ZnO}$ nanoparticles and $\mathrm{Ce}$ ion doped $\mathrm{ZnO}$ nanoparticles synthesized using Sesbaniagrandiflora leaf extract. The dye degradation in presence of bio synthesized nanoparticles was verified by the decrease of the peak intensity during 60min exposure in solar light shown in Fig.16 and Fig.17.The dye degradation (\%) was calculated by using the following equation (2).

$$
\text { Dye degradation }(\%)=\frac{C_{0-} C_{t}}{C_{0}} \quad 100 \%
$$

Where $C_{0}$ is the initial concentration of Bismarck brown and $\mathrm{C}_{\mathrm{t}}$ is the concentration of the dye solution at the selected irradiation time. Fig.18. shows the bleaching of Bismarck brown dye on photodegradation in the presence of $\mathrm{ZnO}$ and $\mathrm{Ce}$ ion doped $\mathrm{ZnO}$ nanoparticles as photocatalyst. The degradation efficiency was higher in the presence of Ce ion doped $\mathrm{ZnO}$ nanoparticles than that for $\mathrm{ZnO}$ nanoparticles.

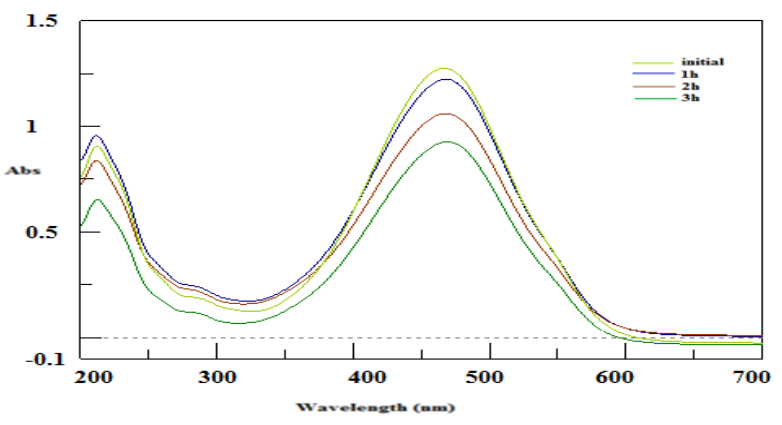

Figure 15: Photocatalytic dye degradation of pure Bismarck brown

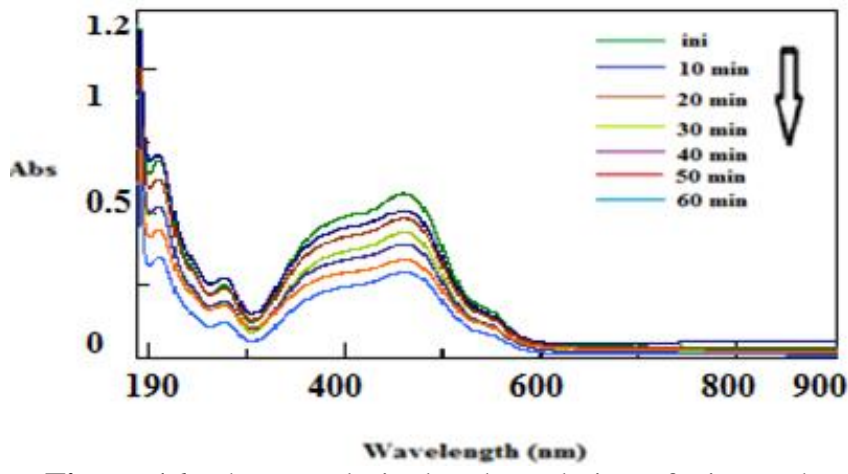

Figure 16: Photocatalytic dye degradation of Bismarck brown in presence of $\mathrm{ZnO}$ nanoparticles synthesized using Sesbaniagrandiflora leaf extract 


\section{International Journal of Science and Research (IJSR) \\ ISSN (Online): 2319-7064 \\ Index Copernicus Value (2013): 6.14 | Impact Factor (2014): 5.611}

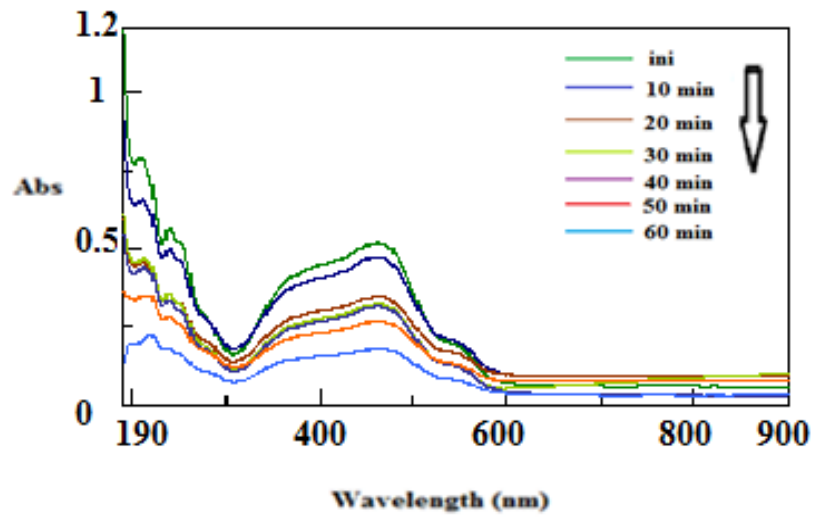

Figure 17: Photocatalytic dye degradation of Bismarck brownin presence of Ce ion doped $\mathrm{ZnO}$ nanoparticlessynthesized using Sesbaniagrandiflora leaf extract

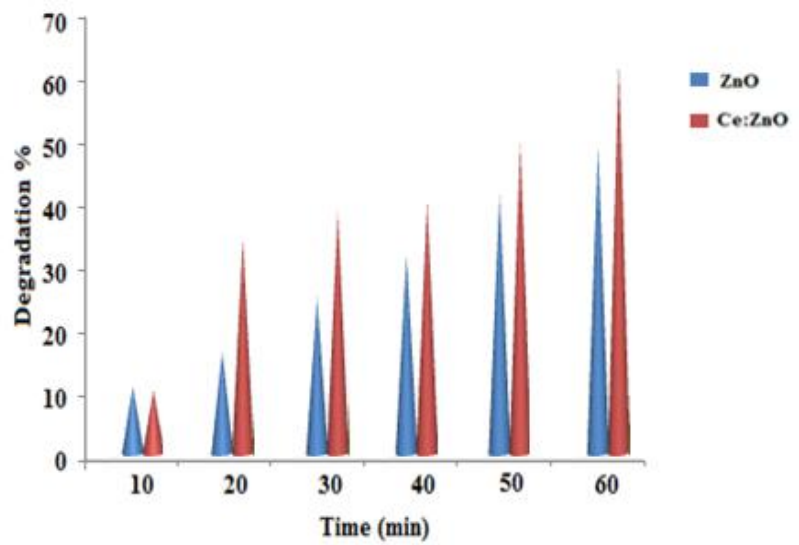

Figure 18: Degradation of Bismarck browndye in the presence of ZnOand Ce ion doped $\mathrm{ZnO}$ nanoparticles synthesized

usingSesbaniagrandiflora leaf extract

\subsection{Conclusion}

$\mathrm{ZnO}$ and $\mathrm{Ce}$ ion doped $\mathrm{ZnOnanoparticles} \mathrm{are} \mathrm{synthesized}$ (simple and cost effective) using aqueous leaf extract of Sesbaniagrandiflora(Agathikeerai). The FT-IR studies showed an absorption peak at $437 \mathrm{~cm}^{-1}$ (Zn-O linkage) which indicated the formation of zinc oxide nanoparticles. The aqueous Sesbaniagrandiflora leaf extract reveals the presence of phyto constituents like alcohol, aldehyde and amine which were the surface active molecules, stabilize the nanoparticles. The surface morphology of the $\mathrm{ZnO}$ and $\mathrm{Ce}$ ion doped ZnOnanoparticles was characterized by SEM analysis and suggested different morphological structures. Chemical purity and stoichiometry of the samples were investigated by EDAX Spectroscopy, in order to confirm the presence of $\mathrm{Zn}, \mathrm{O}$ and Ceions in the material.AFM study reveals the surface morphology of the synthesized $\mathrm{ZnO}$ and Ce ion doped $\mathrm{ZnO}$ nanoparticles. PL Spectra revealed the change of luminescence intensity in the Ce ion doped sample compared to the $\mathrm{ZnO}$ sample with almost a linear increase in excitation intensity. Impedance spectroscopy is employed to study the conductivity of nanoparticles.The conductivity of chemically synthesized nanoparticles is high and is used as an electronic material. The Ce ion doped $\mathrm{ZnO}$ nanoparticles have high $\mathrm{R}_{\mathrm{ct}}$ and low $\mathrm{C}_{\mathrm{dl}}$ values show effective resistance. From cyclic voltammetric studies, good redox behaviour was observed for $\mathrm{ZnO}$ and $\mathrm{Ce}$ ion doped $\mathrm{ZnO}$ nanoparticles synthesized using Sesbaniagrandiflora. The photocatalytic study concludes that these bio-ZnO nanoparticles have efficiency to degrade Bismarck brown dye under solar irradiation. Therefore they can find application in water purification and textile industries.

\section{Acknowledgement}

The authors are thankful to Department of Science and Technology (FAST TRACK and FIST) New Delhi for using Jasco UV-Visible Spectrophotometer and CHI-650 Electrochemical Workstation at V. O. Chidambaram College.

\section{References}

[1] Tundo P. and Anastas P._. Eds, Green Chemistry: Challenging Perspectives. Oxford University Press, Oxford, UK, (2000).

[2] Reed S.M. and Hutchison J.E., "Green Chemistry in the organic teaching laboratory: an environmentally benign synthesis of adipic acid", J ChemEduc77, (2000)16271628.

[3] Deepali Sharma, J.R., B.S. Kaith , MohinderKaur , Sapna Sharma, "Synthesis of $\mathrm{ZnO}$ nanoparticles and study of their antibacterial and antifungal properties", Thin Solid Films519, (2010)1224-1229.

[4] Sangeetha, G., Rajeshwari, S. and Venckatesh, R. Green synthesis of zinc oxide nanoparticles by aloe barbadensis miller leaf extract: Structure and Optical properties, Materials Research Bulletin., 46(12), (2011) 2560-2566.

[5] Gardea-Torresdey, J.L., Parsons, J.G.., Gomez, E. and Peralta Videa, .J. Formation and growth of $\mathrm{Au}$ nanoparticles inside live alfalfa plants, Nanoletters., 2(4), (2002) 397-401.

[6] Huang, J., Li, Q., Sun, D., Lu, Y., Su, Y., and Yang, X. Biosynthesis of silver and gold nanoparticles by novel sundried Cinnamomumcamphora leaf, Nanotechnology., 18(10), (2007) 105104-105114.

[7] Shiv Shankar, S., Rai, A., Ahmad, A., and Sastry, M. Rapid synthesis of Au, Ag, and bimetallic Au core-Ag shell nanoparticles using neem (Azadirachtaindica) leaf broth, Journal of Colloid and Interface Science.,275(2), (2004)496-502.

[8] Ankamwar, B., Chinmay, D., Absar, A., and Murali, S. Biosynthesis of gold and silver nanoparticles using emblicaofficinalis fruit extract, their phase transfer and transmetallation in an organic solution, Journal of Nanoscience and Nanotechnology., 5(10), (2005) 16651671.

[9] Shiv Shankar, S., Rai A., Ankamwar, B., Singh, A., Ahmad, A., and Sastry, M. Biological synthesis of triangular gold nanoprisms, Nature Materials.,3(7), (2004)482-488.

[10] Ankamwar, B. and Chaudhary, M. Gold nanotriangles biologically synthesized using tamarind leaf extract and potential application in vapor sensing, Synthesis and Reactivity in Inorganic and Metal-Organic Chemistry., 35(1), (2005)19-26.

[11] Laldhas, K.P., Cheriyan, V.T., Puliappadamba, V.T., Bava, S.V., Unnithan, R.G., Vijayammal, P.L., and

\section{Volume 5 Issue 3, March 2016}




\section{International Journal of Science and Research (IJSR) \\ ISSN (Online): 2319-7064}

Index Copernicus Value (2013): 6.14 | Impact Factor (2014): 5.611

Anto, R.J. A novel protein fraction from Sesbaniagrandiflorashows potential anticancer and chemopreventive efficacy, in vitro and in vivo, J. Cell Mol. Med., 14(3), (2010) 636-646.

[12] China, R., Mukherjee, S., Sen, S., Bose, S., Datta, S., Koley, H., Ghosh, S., and Dhar, P. Antimicrobial activity of Sesbaniagrandifloraflower polyphenol extracts on some pathogenic bacteria and growth stimulatory effect on the probiotic organism Lactobacillus acidophilus, Microbiol. Res., 167(8), (2012)500-506.

[13] Dethe, U.L., Joshi, S.S., Desai, S.S., and Aparadh, V.T. Screening of bioactive compounds of Sesbaniagrandifloraand Pistiastratiotes, Indian Journal of Advances in plant Research (IJAPR)., 1(1), (2014)2730.

[14] Devdatta, and Appanna,.Nutritive value of Indian foods, Indian Acad. Sci., (1954) 297-398.

[15] Ramesh, P.,Rajendran, A., and Meenakshisundaram, M. Green Syntheis of Zinc Oxide Nanoparticles Using Flower Extract Cassia Auriculata, Journal of Nanoscience and Nanotechnology., 2(1), (2014) 41-45.

[16]Zhihong Jing., Lihua Tan., Fen Li., Jun Wang., Yucai Fu., and Qian Li. Photocatalytic and antibacterial activities of CdS nanoparticles prepared by solvothermal method. Indian Journal of Chemistry.,52A(1), (2013)57-62.

[17] Lin, L., Wang, W., Haung, J., Li, Q., sun, D., Yang, X., Wang, H., He, N., Wang, Y., "Nature factory of silver nanowires: Plant-mediated synthesis using broth of Cassia fistula leaf," J. Chem. Eng., 162, (2010) 852858.

[18] S.R. Senthilkumar, T. Sivakumar, "Green Tea (Camellia Sinensis) mediated synthesis of Zinc Oxide (ZnO) nanoparticles and studies on their antimicrobial activities", International Journal of Pharmacy and Pharmaceutical Sciences, ISSN- 0975-1491 Vol 6, Issue 6, (2014).

[19] Song, J.Y., Jang, H.-K, Kim, B.S., "Biological synthesis of gold nanoparticles using Magnolia kobusand Diopyros kaki leaf extracts," Process Biochem., 44, (2009) 1133- 1138.

[20] Jain, N., Bhargava, A., Majumdar, S., Tarafdar, J.C., Panwar, J., "Extracellular biosynthesis and characterization of silver nanoparticles using AspergillusflavusNJP08: a mechanism perspective," Nanoscale, 3, (2011) 635-641.

[21] SagarRaut, Dr. P. V. Thorat, RohiniThakre, "Green Synthesis of Zinc Oxide ( $\mathrm{ZnO})$ Nanoparticles Using OcimumTenuiflorum Leaves", International Journal of Science and Research (IJSR), Volume 4 Issue 5, May (2015).

[22]K. Ravichandrika et.al, "Synthesis, Characterization and Antibacterial Activity OfZno Nanoparticles", International Journal Of Pharmacy And Pharmaceutical Sciences, Vol 4, Issue 4, (2012) 336- 338.

[23] Sudheesh K. Shukla, Eric S. Agorku, Hemant Mittal, Ajay K. Mishra, "Synthesis, characterization and photoluminescence properties of $\mathrm{Ce}^{3+}$ doped $\mathrm{ZnO}$ nanophosphors", Chemical Papers, (2012) DOI: 10.2478/s11696-013-0442-5.

[24] Ravichandrika, P. Kiranmayi and R.V.S.S.N. Ravikumar, "Synthesis, Characterization and antibacterial activity of $\mathrm{ZnO}$ Nanoparticles”, International Journal of Pharmacy and Pharmaceutical Sciences, ISSN- 0975-1491 Vol 4, Issue 4, (2012).

[25] R. Viswanatha, T.G. Venkatesh, C.C. Vidyasagar, Y. ArthobaNayaka, " Preparation and Characterization of $\mathrm{ZnO}$ and Mg-ZnO nanoparticles", Archives of Applied Science Research, 4 (1)(2012) 480-486.

[26] Elizabeth Varghese and Mary George, "Green Synthesis of Zinc Oxide Nanoparticles", International Journal of Advance Research in Science And Engineering IJARSE, Vol. No.4, Issue No.01, ISSN-2319-8354(E), Jan (2015)307.

[27] DavoodRaoufi, Journal of Luminescence, 134, (2013)213-219.

[28] R.Y. Hong, J.Z. Qian, J.X. Cao, Powder Technol. 163, (2006) 160.

[29] R.Y. Hong, J.H. Li, L.L. Chen, D.Q. Liu, H.Z. Li, Y. Zheng, J. Ding, Powder Technol. 189, (2009) 426.

[30]M. R. Alfaro Cruz, G. Ortega Zarzoza, G. A. MartínezCastañón and J. R. Martínez, "Thin films from different materials obtained by the Sol-Gel method: study of the morphology through Atomic Force Microscopy (AFM)". 